\title{
Fitness and Bodybuilding as A Physical Activity and its Importance for Physical Development, Physical Fitness and Mental Wellbeing
}

\author{
Josef Oborný \\ Professor of the Faculty of Physical Education and Sports, \\ Comenius University in Bratislava. \\ Ivana Ferenc \\ PhD student of the Faculty of Physical Education and Sports, \\ Comenius University in Bratislava.
}

\begin{abstract}
Nowadays, bodybuilding is already popular amongst the youth to a high degree. It is of great significance that all admirers of this sport are focused in the right direction. In order for a person to get on the right track, there is necessary an excellent teacher to show and teach them the correct way. A properly chosen personal trainer is a first precondition for success, followed by motivation and will of each and every one of us. Bodybuilding as a physical activity has a remarkable importance for physical, mental and aesthetical development of an individual. This sport has greatly contributed to the development of knowledge of body aesthetics, patterns in the field of an athlete's nutrition and methodology of development of strength and muscle volume.
\end{abstract}

Key words: bodybuilding, sport, personal trainer, physical activity, motivation, lifestyle, body aesthetics, self-confidence

\section{INTRODUCTION}

The word sport comes from the Latin word disportare, which translates to - to be entertained. Initially, in antique culture and ancient civilizations, sport was an amusement for people and had recreational character (Perútka et al., 1982). Over time, however, it has gradually started to change and evidence of that change can be seen in today's modern sport, which is now an integral part of people's cultural and social lives; it is no longer just a leisure activity but represents a lifestyle, professional occupation and contributes to the creation of new cultural values of society.

Oborný $(2015,139)$ describes contemporary sport „as a cultural phenomenon in two planes. We understand sport from the $19^{\text {th }}$ to the $20^{\text {th }}$ century as an integral part of the general human culture as a general cultural artefact. In connection with civilizations in sport, all compatible features of today's civilizations, whose members (in this case mostly athletes and sports spectators) participate in major (global) sporting events, manifest real functionality. The second plane of this observation of sport moves to the forefront its aesthetical aspects." The first plane is also confirmed by Labudová and Sakáčová (2015), according to whom individuals and groups in sport work together as well as compete against each other while forming and creating social bonds in sporting community from different social environments, interests and various areas of life. Sports competitions are therefore an original and unique contribution to social values.

Globalization and hectic lifestyle is characteristic for the $21^{\text {st }}$ century as a result of a hectic era. This hectic lifestyle, however, is not a sign of an active and healthy lifestyle. It all brings a lot of 
opportunities and possibilities for reaching personal maximum, but in a very short time and with a risk of unexpected sacrifices. The rapid pace of a present-day life can result in a loss of an individual's cultural identity, which only makes him a plain consumer. It is essential to find room for self-reflection. Even Socrates knew that intellectual self-awareness based on psychological observation of oneself is the main virtue of human activity. It stands true also in bodybuilding that the usefulness of practising active health and lifestyle "as a part of important activities and relations and with them connected practices leads to achievement of a full and harmonious state between physical and mental aspects of life" (Sekot, 2015).

\section{Bodybuilding as a physical activity}

Bodybuilding is characterized as a sector of sport focused on the systematic and methodical development of muscles with the purpose of strengthening health, learning proper body posture, but also developing strength and stamina (Demetrovič, 1988). However, one cannot forget the fact that bodybuilding holds a specific function of body aesthetics for a human. This factor can furthermore lead to a boost in athlete's confidence, since it is in the sport where the athlete's body is an indicator of his performance. According to Ferenc (2007), the mentioned sports performance depends mostly on the individual differences of each person:

- Body structure - genetic predisposition, somatotype ${ }^{1}$, muscle proportions

- Metabolism - energy metabolism, $\mathrm{BMR}^{2}$, body fat percentage

- Volitional and personality features - character, upbringing, self-denial

- Methodology of training and the attitude towards it - exercise, training programs, intensity, conducting and guidance of sports preparation/trainings

- Social environment for realization of sports performance - family, sports and working environment

As a sports discipline, bodybuilding is divided into a non-competitive bodybuilding, which represents the recreational exercise or rather a certain kind of a long-term lifestyle, and $a$ competitive bodybuilding, which includes competitions in amateur and professional divisions. Professionals compete only in two weight categories (up to $96 \mathrm{~kg}$ and over $96 \mathrm{~kg}$ ) and the amateur bodybuilding comprises sports, classical and natural section where athletes compete in:

- weight categories (sports bodybuilding),

- categories with a principle of height-weight ratio (classical and natural bodybuilding).

Decision-making during competitions is based on 4 factors that the athlete's performance (meaning the body) must show:

- muscle development,

- balance of muscular development,

- muscle definition,

- and density of the muscles.

A typical feature of bodybuilding as a sports discipline, which significantly differs it from other sports, is the difference between the preparation of sports performance and its presentation -

\footnotetext{
${ }^{1}$ Morphological features and functional predispositions of the shape and composition of a human body were identified by W. H. Sheldon as a somatotype. Based on the method of physical type, he divides people into three basic somatotypes: endomorph (e.g. sumo wrestler), mesomorph (e.g. bodybuilder), ectomorph (e.g. endurance runner) (Vilikus et al., 2013).

2 Basal metabolism - minimal energy requirement necessary for maintaining basic life functions (Vilikus et al., 2013).
} 
a gym vs. a hall with a stage (Vigneau, 1998). This aspect of environmental disparity plays a key role, because it can affect the competitor's psyche. There even occurred cases, where athletes refused to take part in the competition because they had not been able to perform satisfactorily in the same particular hall the previous season (Ferenc - Čepčeková, 2013).

\section{Advantages and the importance of bodybuilding}

The question of beauty has already been dealt with by ancient philosophers, and today aesthetics is a separate scientific discipline with its main interest being the aforementioned beauty. The body represents the means of connecting a human with the world, which significantly affects self-definition (it determines the physical identity of mankind). The allure of a human body is a result of innate dispositions and cultural, even social influences that determine aesthetical ideals and norms (Fialová, 2006).

Due to some external influences (exercise, weightlifting, cosmetics, plastic surgery and others), it is possible to transform and shape the human body. This is where the field of bodybuilding has also found its place, meaning that in bodybuilding the body of an athlete is the main centre of attention. Every bodybuilder pays great attention to their appearance, has a relationship with their body, which answers the question of their own self-assessment. High or adequate self-evaluation is essential in life because it is related to life satisfaction, independence, positive social adaptation and better management of stressful situations. Every athlete knows the relationship between their body and themselves, which positively affects the psychical side of their personality. Reasonable self-evaluation carries with it a healthy self-confidence, which is followed by self-esteem, which is an important prerequisite for the mental wellbeing of a human (Ferenc, 2007). Emphasis on appearance and the figure ought to be considered as one of the positive aspects of this sport, as they undoubtedly affect the social interactions of the particular human.

As we have already mentioned, we cannot omit the fact, that fitness and bodybuilding both hold a specific aesthetical function for a person, enabling the athlete to improve their figure and thus lift their self-confidence. This sector of sport is also undeniably beneficial for physical, mental and aesthetical development of an individual.

Despite some of the negative phenomena that accompanies bodybuilding today, one cannot forget that this sport has greatly contributed to the knowledge of nutritional patterns and methodology of development of strength and muscle volume. To this day, this sports sector has many loyal supporters for whom bodybuilding means a long-term lifestyle (Ferenc, 2015).

\section{OBJECTIVE, TASKS AND METHODOLOGY OF WORK}

Our objective was to find personality and motivational qualities of the respondents - why they have taken part in the course Personal trainer in fitness and bodybuilding of the $1^{\text {st }}$ qualification degree, which is organized all year round by a training facility accredited by the Ministry of Education of the Slovak Republic titled Sports Consultation - Inform, LLC. In particular, we focused on identifying their interest in fitness and bodybuilding with appropriately defined closed and semi-closed questions in a non-standardized questionnaire. Using this method, we have investigated why the future trainers have chosen this sport as their mission, whether they want to practice the particular subject even after the training ends or whether they have come with a simple intention of obtaining a licence for administrative purposes. The questionnaire method found a wide range of application in our research. According to Leška (2005) this interrogative method allows to collect a lot of data from a great amount of people in a relatively short time and with relatively low costs. 
We assumed that most of the respondents had taken part in the course because of their interest in fitness and bodybuilding, but we did not refuse other options as well. The collected questionnaires were evaluated via qualitative and quantitative mathematical and statistical methods.

The ultimate goal of our work is to motivate people to sport, whether through personal trainers (whose motivational qualities for becoming a trainer we made a point to verify) or through personally motivating abilities. We want bodybuilding, or its equivalent - fitness, to become a source of self-realization, professionalism, to become the content of the lifestyle of individuals both in a competitive and non-competitive form and become a disseminator of a good name for this sport.

The observed unit (participants of the above-mentioned course) consisted of the total amount of 77 respondents, of whom 25 were women and 52 were men, with male sex portraying a considerable preponderance over the female sex - 68\%. In terms of the age structure of respondents, the prevailing age category was 21 - 29 years (45\%), followed by the age category 30 - 35 years (23\%). The least represented were participants aged 46 and over, who equalled only to $4 \%$ of respondents. Everyone's task was to fill in the questionnaire, in which they answered questions based on which we were able to evaluate their personality and motivational qualities of participation in the course.

Table 1

Characteristics of the observed unit according to gender (figures in the table represent the occurrence of a specific category in percentage)

\begin{tabular}{lccc}
\hline & \multicolumn{2}{c}{ Gender } & \\
\cline { 2 - 3 } Age & Men & Women & Total \\
\hline $15-20$ years & $12 \%$ & $0 \%$ & \\
\hline $21-29$ years & $48 \%$ & $40 \%$ & $45 \%$ \\
$30-35$ years & $15 \%$ & $40 \%$ & $23 \%$ \\
$36-45$ years & $19 \%$ & $20 \%$ & $19 \%$ \\
46 years and over & $6 \%$ & $0 \%$ & $4 \%$ \\
\hline
\end{tabular}

\section{RESULTS OF THE RESEARCH}

The intention of one of our questionnaire questions was to find out from the interviewees why they have decided to become personal trainers. In this item, respondents could select more answers, choosing from the options: it is my lifestyle, it is my hobby, it is my occupation, I want to learn how to exercise, others. As a relatively large proportion of respondents selected several of the offered options, we calculated the percentage of each of the answers in each response (e.g. answer it is my hobby occurred in 31 out of 77 possible cases, therefore the percentage representation is $31 / 77=40 \%$ ).

From Table 2 we can clearly identify that the most common reasons why respondents have decided to become fitness and bodybuilding trainers are items it is my lifestyle (73\%) and it is my hobby (40\%). 
Table 2

Relative variability of occurrences of individual options categorized according to gender

\begin{tabular}{|c|c|c|c|}
\hline \multirow{2}{*}{$\begin{array}{c}\text { Why have you decided to become a } \\
\text { personal trainer in fitness and } \\
\text { bodybuilding? }\end{array}$} & \multicolumn{2}{|c|}{ Gender } & \multirow[b]{2}{*}{ Total } \\
\hline & Men & Women & \\
\hline it is my lifestyle & $73 \%$ & $72 \%$ & $73 \%$ \\
\hline it is my hobby & $37 \%$ & $48 \%$ & $40 \%$ \\
\hline it is my occupation & $10 \%$ & $8 \%$ & $9 \%$ \\
\hline I want to learn how to exercise & $14 \%$ & $24 \%$ & $17 \%$ \\
\hline others & $12 \%$ & $16 \%$ & $13 \%$ \\
\hline
\end{tabular}

Nearly three quarters of men and women state, that the reason why they want to become a personal trainer in fitness and bodybuilding is that it is their lifestyle; women, compared to men, more frequently cite reason that it is their hobby, or that they want to learn how to exercise. At the same time, women list more reasons than men.

Analogously, we analysed the respondents' answers with respect to age (see Table 3). It is my lifestyle is the most common reason in age categories under 35, I want to learn how to exercise is the most frequently chosen reason in age group over 30, it is my hobby is a fairly prevalent reason among the ages between 21 and 45 years.

Table 3

Relative variability of occurrences of individual options categorized according to age

\begin{tabular}{lcccccc}
\hline $\begin{array}{l}\text { Why have you decided } \\
\text { to become a personal } \\
\text { trainer in fitness and } \\
\text { bodybuilding? }\end{array}$ & $15-20 \mathrm{y}$ & $21-29 \mathrm{y}$ & $30-35 \mathrm{y}$ & $36-45 \mathrm{y}$ & $>46 \mathrm{y}$ & Total \\
\hline $\begin{array}{l}\text { it is my lifestyle } \\
\text { it is my hobby }\end{array}$ & $03 \%$ & $74 \%$ & $78 \%$ & $60 \%$ & $67 \%$ & $73 \%$ \\
$\begin{array}{l}\text { it is my occupation } \\
\text { I want to learn how to }\end{array}$ & $0 \%$ & $11 \%$ & $6 \%$ & $7 \%$ & $33 \%$ & $9 \%$ \\
$\begin{array}{l}\text { exercise } \\
\text { others }\end{array}$ & $17 \%$ & $0 \%$ & $39 \%$ & $27 \%$ & $33 \%$ & $17 \%$ \\
Total & $0 \%$ & $9 \%$ & $17 \%$ & $13 \%$ & $67 \%$ & $13 \%$ \\
\hline
\end{tabular}

In the next questionnaire question, we looked into forms in which the participants of the course engage in fitness and bodybuilding. Respondents were given a choice from these options: I work out for myself, I train clients and acquaintances, I work out for myself while training clients and acquaintances, I do not enjoy fitness and bodybuilding, or I do not exercise, other forms.

The prevailing answer was I work out for myself (68\%), and the second most common answer was I work out for myself while training clients and acquaintances (25\%), only 5\% of respondents engage in sole training of clients, or acquaintances.

By gender categorization of respondents, we learnt that women work out for themselves to a greater extent than men ( $83 \%$ vs. $61 \%$ ) and on the other hand, men tend to focus more on training of clients, or acquaintances. 


\section{Figure 1}

Categorized bar chart of respondents' answers to the question In which forms do you engage in fitness and bodybuilding?

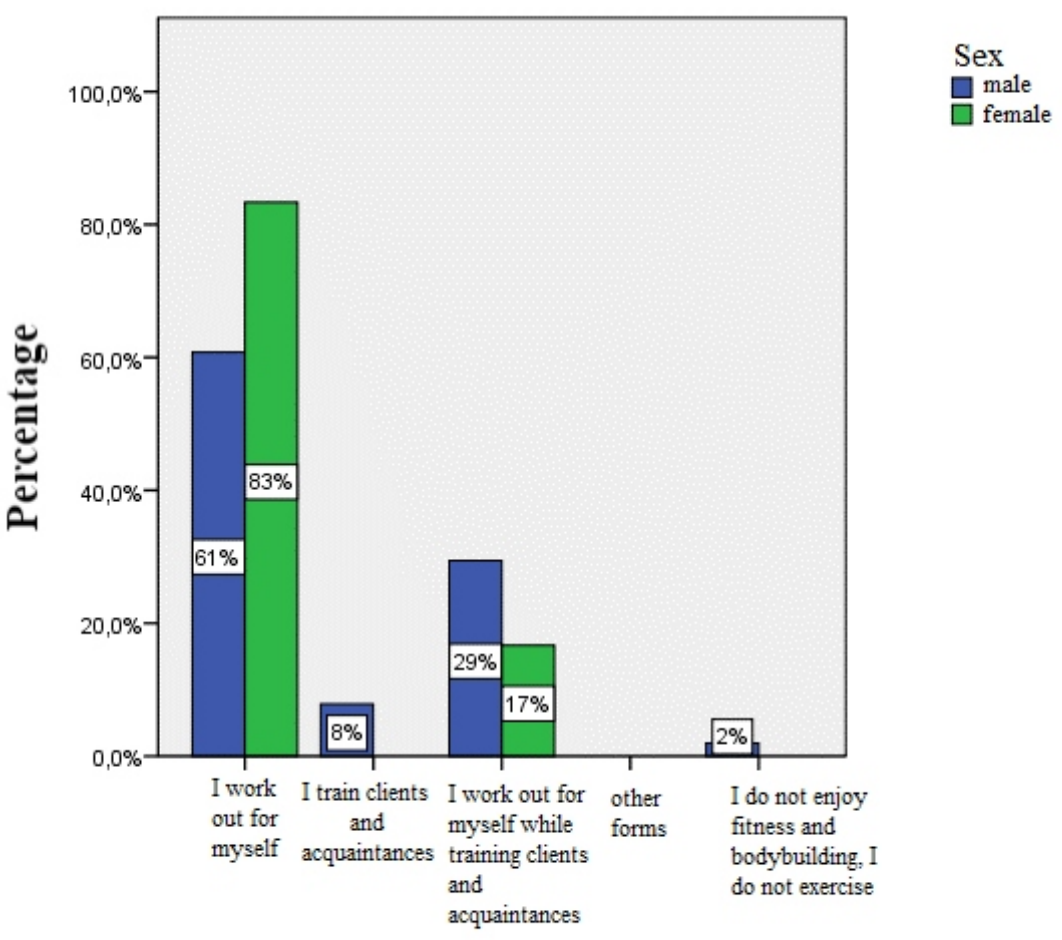

In which forms do you engage in fitness and bodybuilding?

By age categorization of respondents (see Table 4), we found out that in each age group, answer I work out for myself dominates, but among older respondents (over 36 years), the second most favoured response is I train clients and acquaintances, while among younger respondents (35 and less) it is the option I work out for myself while training clients and acquaintances.

Table 4

Relative occurrences of respondents' answers to a question In which forms do you engage in fitness and bodybuilding? categorized according to the age of the observed unit

\begin{tabular}{|c|c|c|c|c|c|c|}
\hline \multirow{2}{*}{$\begin{array}{l}\text { In which forms do you engage in } \\
\text { fitness and bodybuilding? }\end{array}$} & \multicolumn{5}{|c|}{ Age } & \multirow[b]{2}{*}{ Total } \\
\hline & $15-20 y$ & $21-29 y$ & $30-35 y$ & $36-45 y$ & $>46 y$ & \\
\hline I work out for myself & $50 \%$ & $67 \%$ & $67 \%$ & $80 \%$ & $67 \%$ & $68 \%$ \\
\hline I train clients and acquaintances & $0 \%$ & $3 \%$ & $0 \%$ & $13 \%$ & $33 \%$ & $5 \%$ \\
\hline $\begin{array}{l}\text { I work out for myself while training } \\
\text { clients and acquaintances } \\
\text { I do not enjoy fitness and }\end{array}$ & $50 \%$ & $27 \%$ & $33 \%$ & $7 \%$ & $0 \%$ & $25 \%$ \\
\hline bodybuilding, or I do not exercise & $0 \%$ & $3 \%$ & $0 \%$ & $0 \%$ & $0 \%$ & $1 \%$ \\
\hline Total & $100 \%(6)$ & $100 \%(35)$ & $100 \%(18)$ & $100 \%(15)$ & $100 \%(3)$ & $100 \%(77)$ \\
\hline
\end{tabular}

The following question in the questionnaire was - How often do you train clients or acquaintances? Respondents could opt for one of these answers: I do not train, twice a week, three times a week, four times a week, more than four times a week, every day.

The most favoured responses were three times a week (28\%), four times a week (24\%), more than four times a week (23\%). The least favoured one was the answer I do not train (5\%). In case of women, training three times a week is dominant (39\%), while men are in a different 
situation - training three times a week, four times a week and more than four times a week all equally dominate with roughly the same percentage of $25 \%$. This means that men train their clients and acquaintances more often than women (see Figure 2).

The intensity of client training among respondents aged 21-29 years, 30-35 years and 36-45 years is very similar, while training more than three times a week prevails. On the other hand, among respondents of age groups 15-20 years and over 46 years, training more than four times a week does not occur (see Table 5).

Table 5

Relative occurrences of respondents' answers to a question How often do you train clients or acquaintances? categorized according to the age of the observed unit

\begin{tabular}{lcccccc}
\hline \multicolumn{1}{c}{$\begin{array}{c}\text { How often do you train } \\
\text { clients or acquaintances? }\end{array}$} & $15-20 \mathrm{y}$ & $21-29 \mathrm{y}$ & $30-35 \mathrm{y}$ & $36-45 \mathrm{y}$ & $>46 \mathrm{y}$ & Total \\
\hline I do not train & $17 \%$ & $3 \%$ & $6 \%$ & $7 \%$ & $0 \%$ & $5 \%$ \\
twice a week & $17 \%$ & $9 \%$ & $6 \%$ & $0 \%$ & $33 \%$ & $8 \%$ \\
three times a week & $17 \%$ & $21 \%$ & $35 \%$ & $33 \%$ & $67 \%$ & $28 \%$ \\
four times a week & $50 \%$ & $24 \%$ & $12 \%$ & $33 \%$ & $0 \%$ & $24 \%$ \\
more than four times a & & & & & & \\
week & $0 \%$ & $27 \%$ & $29 \%$ & $20 \%$ & $0 \%$ & $23 \%$ \\
every day & $0 \%$ & $15 \%$ & $12 \%$ & $7 \%$ & $0 \%$ & $11 \%$ \\
Total & $100 \%(6)$ & $100 \%(33)$ & $100 \%(17)$ & $100 \%(15)$ & $100 \%(3)$ & $100 \%(74)$ \\
\hline
\end{tabular}

Figure 2

Categorized bar chart of respondents' answers to a question How often do you train clients or acquaintances? according to sex
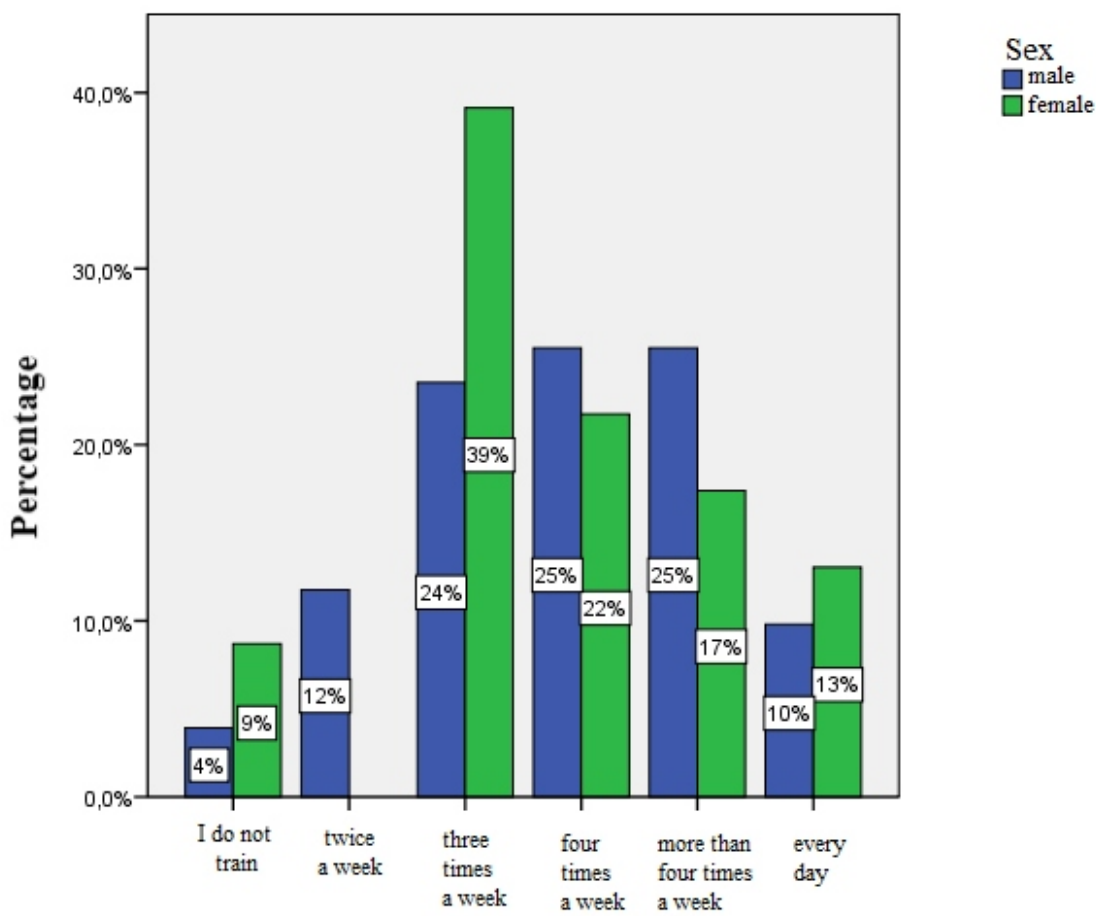

How often do you train clients or acquaintances?

In question What does fitness and bodybuilding mean to you? respondents could choose one of the options: lifelong perspective, definitely a long-term perspective of sports activities, activity 
that follows my previous sports activity and after fitness and bodybuilding I might try something different, one of many hobbies, others.

The most common responses were lifelong perspective (44\%), long-term perspective of sports activities (32\%), one of many hobbies (19\%). Option chosen the least was activity that follows my previous sports activity and after fitness and bodybuilding I might try something different $(1 \%)$. For women who have participated in the schooling of how to train, fitness and bodybuilding especially mean a lifelong perspective (58\%); among men it is approximately the same lifelong perspective (37\%) and a long-term perspective of sports activities (39\%).

The last questionnaire question that we have asked our respondents concerned what they would like to do after finishing the course Personal trainer in fitness and bodybuilding. They could choose one of the options: training, regular exercising, setting up my own training practice, I took part in the course out of curiosity, I will not further continue in this area, others.

Respondents most often reported that after finishing the course, they would like to engage in regular exercising (49\%), training (28\%), or training as well as regular exercising (19\%). About $1 \%$ of those questioned is considering setting up their own practice.

What is striking is that women would like to engage in training, or training as well as regular exercising much more than men, while men, as opposed to women, prefer regular exercising (see Figure 3).

Figure 3

Categorized bar chart of respondents' answers to a question What would you like to do after finishing the course "Personal trainer in fitness and bodybuilding"? according to sex

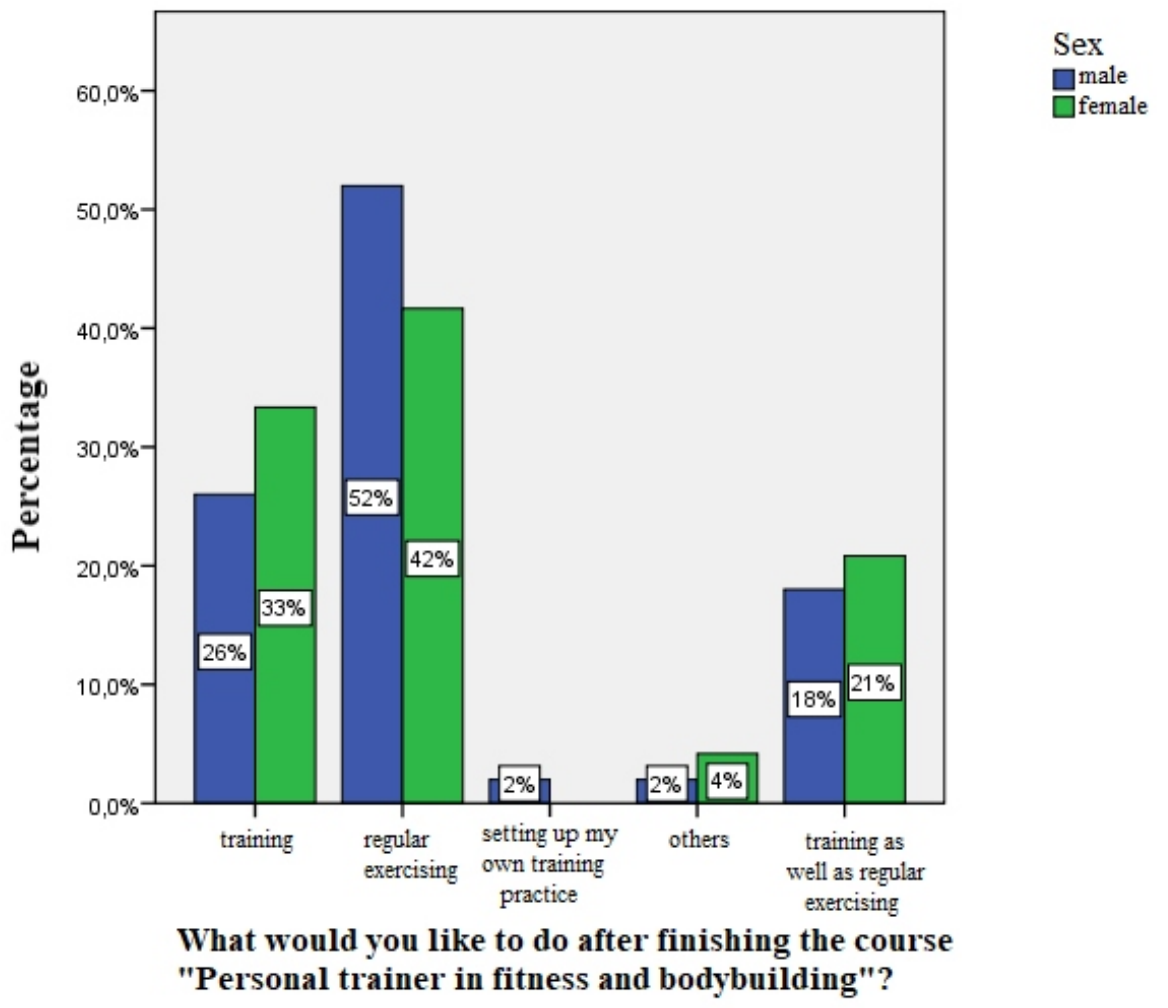

What is interesting is the fact that with the growing age of respondents, the interest to exercise regularly in the future increases. In case of training, it is rather the opposite - the higher the age, the lower the desire to train others. 
Table 6

Relative occurrences of respondents' answers to a question What would you like to do after finishing the course "Personal trainer in fitness and bodybuilding"? according to the age of the observed unit

\begin{tabular}{|c|c|c|c|c|c|c|}
\hline \multirow{2}{*}{$\begin{array}{l}\text { What would you like to } \\
\text { do after finishing the } \\
\text { course "Personal } \\
\text { trainer in fitness and } \\
\text { bodybuilding"? }\end{array}$} & \multicolumn{5}{|c|}{ Age } & \multirow[b]{2}{*}{ Total } \\
\hline & $15-20 y$ & $21-29 y$ & $30-35 y$ & $36-45 y$ & $>46 y$ & \\
\hline training & $17 \%$ & $38 \%$ & $28 \%$ & $20 \%$ & $0 \%$ & $28 \%$ \\
\hline regular exercising & $33 \%$ & $47 \%$ & $50 \%$ & $53 \%$ & $67 \%$ & $49 \%$ \\
\hline $\begin{array}{l}\text { setting up my own } \\
\text { training practice }\end{array}$ & $0 \%$ & $0 \%$ & $0 \%$ & $7 \%$ & $0 \%$ & $1 \%$ \\
\hline others & $0 \%$ & $0 \%$ & $6 \%$ & $0 \%$ & $33 \%$ & $3 \%$ \\
\hline $\begin{array}{l}\text { training as well as } \\
\text { regular exercising }\end{array}$ & $50 \%$ & $16 \%$ & $17 \%$ & $20 \%$ & $0 \%$ & $19 \%$ \\
\hline Total & $100 \%(6)$ & $100 \%(32)$ & $100 \%(18)$ & $100 \%(15)$ & $100 \%(3)$ & $100 \%(74)$ \\
\hline
\end{tabular}

\section{DISCUSSION}

Based on our findings, we have verified that age or sex are not determining factors that would influence the interest in bodybuilding or that they also do not stand in the way of motivation of personal trainers to become disseminators of a good name for this sport.

According to American research, men and women who do bodybuilding are much more satisfied with their bodies than athletes whose activity is not focused on the direct building or strengthening of muscle mass, and also people with an inactive lifestyle (Pasman - Thompson, 1988).

As reported by Čechák and Linhart (1986), as well as many other authors, sport in today's society has started to express an individual life orientation, specific and ethical worldview of people. It represents a certain lifestyle, values and besides trying to achieve a specific perfection, as far as physical fitness is concerned, it is already firmly connected with an idea and image of a new way of life and values. Our objective is to create such orientation of values in bodybuilding, which will be motivated by the fair play, which emphasizes friendship, respect for others, respect for rules, self-control or true self-knowledge and self-expression (Bednáŕ, 2009). The findings of our research tend towards these values, although they were not the subject of our scientific research.

With our research, we have confirmed that values of bodybuilding and fitness will be spread through the respondents in the right direction, since in most cases bodybuilding means a lifelong perspective, a hobby and it expresses a certain lifestyle to our prospective trainers. For the sector of bodybuilding, just as for any other sector of sport, it stands true that sport "as a whole is in many ways a consequence, initiator and also a manifestation of dynamics of the life of a modern day human, manifestation of dynamics of the changes of today's world (...) It is an important and influential social and human phenomenon of the present. It became a part of working life as well as leisure time, hence it became an occupation just as an entertainment for a large amount of people" (Oborný, 2015). The choice of sport, from the perspective of the particular person, is not easy and oftentimes reasonable, therefore we should prove through our trainers, that the given individual has made a correct choice when choosing bodybuilding. 


\section{CONCLUSION}

A part of the constant development of sport as a whole is the fact that it also affects individual sports disciplines, in which bodybuilding is also included. The overall significance of this sport activity as well as the importance of physical culture stems from the fact that it is a part of life of not only society, but also of an individual. Movement itself is a natural expression of man, it possesses a vital function, which is a basic condition for physical as well as mental health. Regular physical activity prolongs life and improves its quality. Based on this fact, we are very glad for the accumulated results that have shown that the interest in bodybuilding of our respondents is not faked, which is an excellent personal precondition and potential for carrying out their mission of being a trainer conscientiously and correctly in the spirit of preserving the essence of physical culture.

\section{BIBLIOGRAPHY}

BEDNÁŘ, M. Pohyb člověka na biodromu. Cesta životem z pohledu (nejen) kinantropologie. [Human movement on bio droma. The way of life from the perspective of (not only) kinanthropology]. 2009. Praha: Karolinum, 2009, 190 p. ISBN 98-80-246-1665-0.

ČECHÁK, V., LINHART, J. 1986. Sociologie sportu. [Sociology of sport]. Praha: Olympia, 1986. 240 p.

ČELIKOVSKÝ, S. et al. 1986. Kritéria a normy tělesné př́pravy a výkonnosti. [Criteria and standards body preparation and performance]. Praha: Univerzita Karlova, 1986, 440 p.

DEMETROVIČ, E. et al. 1988. Encyklopedie tělesné kultury (A - O). [Encyclopedia of Body Culture, A-O]. Praha, Bratislava: Olympia, Šport, 1988, 464 p.

FERENC, I. Metamorfózy vo fitnes a kulturistike v 21. storočí. [Socio-anthropological metamorphosis in the fitness and bodybuilding in the 21st century]. 2015. In OBORNÝ, J., ŠTAUD, O., VRTIAKOVÁ, B. (eds.). Kultúrna antropológia a šport. Zborník vedeckých prác. [Cultural anthropology and sport. Collection of reviewed scientific papers]. Bratislava: FTVŠ UK, 2015, p. 33 - 41. ISBN 978-80-223-3952-0.

FERENC, P. 2007. Sociálne aspekty športového výkonu v športovej kulturistike. Dizertačná práca [Social Aspects of Sports Performance in Sports Bodybuilding Dissertation thesis]. Bratislava: FTVŠ UK, 2007, 126 p.

FERENC, P., ČEPČEKOVÁ, I. 2013. Využitie introspekcie v kulturistike. [Utilization of introspection in bodybuilding]. In Športový edukátor. Nitra: PF UKF, 2013, vol. 6, no. 2, p. 80-83. ISSN 1337-7809.

FIALOVÁ, L. 2006. Moderní body image. Jak se vyrovnat s kultem štíhlého těla. [Modern body image. Slim body]. Praha: Grada Publishing, 2006, 92 p. ISBN 80-247-1350-0.

LABUDOVÁ, J., SAKÁČOVÁ, Z. 2015. Kultúrno-spoločenské hodnoty synchronizovaného plávania v kontexte prvých európskych hier. [Current path of cultural and social synchronized swimming values in the context of the first european games]. In OBORNÝ, J., ŠTAUD, O., VRTIAKOVÁ, B. (eds.). Kultúrna antropológia a šport. Zborník vedeckých prác. [Cultural anthropology and sport. Collection of reviewed scientific papers]. Bratislava: FTVŠ UK, 2015, p. 109-116. ISBN 978-80-223-3952-0.

LEŠKA, D. 2005. Sociológia športu. [Sociology of sport]. Bratislava: ICM Agency, 2005, 272 p. ISBN 80-969268-4-5. OBORNÝ, J. Filozofia a šport [Philosophy and sport]. 2015. Bratislava: Univerzita Komenského, 2015, 158 p. ISBN987-80-223-3659-7.

OBORNÝ, J. Šport a civilizácie. [Sport and civilizations]. 2015. In OBORNÝ, J., ŠTAUD, O., VRTIAKOVÁ, B. (eds.). Kultúrna antropológia a šport. Zborník vedeckých prác. [Cultural anthropology and sport. Collection of reviewed scientific papers]. Bratislava: FTVŠ UK, 2015, p. 125-140. ISBN 978-80-223-3952-0.

OBORNÝ, J., ŠTAUD, O., VRTIAKOVÁ, B. (eds.). Kultúrna antropológia a šport. Zborník vedeckých prác. [Cultural anthropology and sport. Collection of reviewed scientific papers]. 2015. Bratislava: FTVŠ UK, 2015, 217 p. ISBN 978-80-223-3952-0.

PASMAN, L. - THOMPSON, J. K. 1988. Body image and eating disturbance in obligatory runners, obligatory weightlifters, and sedentary individuals. In International Journal of Eating Disorders. 1988, vol. 7, no. 1, p. 759-769.

PERÚTKA, J. a kol. 1982. Malá encyklopédia telesnej výchovy a športu. [Small Encyclopedia of Physical Education and Sports]. 2. ed. Bratislava: Obzor, 1982, 728 p.

SEKOT, A. 2015. Pohybové aktivity pohledem sociologie. [Physical activity through sociology]. Brno: Masarykova univerzita, 2015. ISBN 978-80-210-7918-2. 
Oborný, J., \& Ferenc, I. (2019). Fitness and Bodybuilding as A Physical Activity and its Importance for Physical Development, Physical Fitness and Mental Wellbeing. Advances in Social Sciences Research Journal, 6(2) 112-122.

SINN, U. 2003. Olympia. Kult, sport a slavnost v antice. [Olympia. Cult, sport and festivities in antikvity]. Praha: Epocha, 2003. 120 p. ISBN 80-86328-20-1.

ŠVUB, J. 1997. Historie síly. [History of strength]. Pardubice: Svět kulturistiky, 1997, 246 p.

VIGNEAU, F. 1998. Les espaces du sport. Paris: Presse Universitaire de France, 1998, 127 p. ISBN 2-13-049432-3.

VILIKUS, Z. a kol. 2013. Výživa sportovců a sportovní výkon. [Athlete nutrition and sports performance]. Praha: Karolinum, 2013, 177 p. ISBN 978-80-246-2064-0. 